\title{
Quantification of HLA class I molecules on renal cell carcinoma using Edman degradation
}

\author{
Juliane S Stickel ${ }^{1}$, Natalie Stickel ${ }^{3}$, Jörg Hennenlotter ${ }^{2}$, Karin Klingel ${ }^{4}$, Arnulf Stenzl ${ }^{2}$, Hans-Georg Rammensee ${ }^{1}$, \\ Stefan Stevanović 1* $^{*}$
}

\begin{abstract}
Background: Unimpaired HLA class I antigen presentation is a prerequisite for the recognition of tumor cells by cytotoxic T lymphocytes and thus essential for the success of anticancer immunotherapeutic concepts. Several approaches have been taken in the immunotherapy of metastatic renal cell carcinoma (RCC), however of limited success. HLA loss or down-regulation have often been reported and might interfere with immunotherapeutic approaches aimed at the recognition of HLA-presented peptides.
\end{abstract}

Methods: We employed a quantitative method of molecular analysis for the comparison of HLA amounts on primary tumor, normal kidney and metastases of RCC, using Edman degradation. We analyzed a series of 47 RCC samples including corresponding renal parenchyma, local lymph node metastases and distant metastases.

Results: Results of quantitative Edman degradation revealed significantly higher HLA yields on primary tumor and metastases compared to normal kidney tissue. This effect was shown not to result from infiltrating immune cells, since tumor-infiltrating lymphocytes had no influence on the overall HLA recovery from tumor tissue. Unexpectedly, we found a higher amount of HLA class I molecules on distant metastases compared to local lymph node metastases.

Conclusion: Edman degradation allows the direct quantitative comparison of HLA class I protein expression by tumor or normal tissue and metastases of RCC patients. Our results raise hopes for improving the success and effectiveness of future immunotherapeutic concepts for metastatic RCC.

\section{Background}

Metastatic renal cell carcinoma (RCC) remains a disease with fatal prognosis that is responsible for almost 100,000 deaths per year [1]. It is the most common malignant tumor in adult kidney, accounting for approximately $3 \%$ of human malignancies. Metastatic RCC is still a challenging tumor entity even though various strategies for chemotherapy have been developed in recent years $[2,3]$

The high immunogenicity of RCC has led to several immunotherapeutic concepts, starting with IFNa/IL-2 treatment [4] and advancing over numerous studies using cell-based vaccines to vaccination therapy with HLA-presented peptides derived from tumor-associated antigens [5-8]. Although some immunotherapeutic

\footnotetext{
* Correspondence: stefan.stevanovic@uni-tuebingen.de

'Department of Immunology, Institute for Cell Biology, University of

Tübingen, Germany Full list of author information is available at the end of the article
}

studies for metastatic RCC have found their way into the clinic [9-11], the clinical results of cancer immunotherapy are still below expectation.

Most immunotherapeutic concepts focus on HLA class I molecules, which are necessary for antigen presentation to cytotoxic T cells (CTLs). Even today the critical amount of HLA class I complexes on the cell surface that leads to $\mathrm{T}$ cell activation has still not been finally clarified - specifications vary between a few thousand and under ten $[12,13]$. Nevertheless, HLA class I altered expression on cancer cells still represents one of the most important mechanisms of tumor escape from immune response that eventually leads to accumulation of new variants with low immunogenicity and high capability for metastatic progression [14,15]. For this reason, the presentation of HLA class I antigens on tumor cell surface seems to be one of the main factors impairing the success and clinical outcome of peptidebased cancer vaccines aimed at increasing specific
C Biomed Central 
anti-tumor activity of CTLs [16]. Altered tumor expression of HLA class I is frequently observed in various types of malignancies and in some cases it has been associated with poor clinical prognosis [17-19]. In case of RCC, the downregulation or loss of HLA-class I has also been described [20,21], as well as overexpression of HLA class I on RCC compared to normal kidney tissue [22]. However, the quantification in these studies was only determined indirectly with immunohistochemistry or on mRNA level by gene expression analysis. While immunohistochemistry as a semi-quantitative method sheds a spotlight on only one layer of tissue, mRNA levels do not always correlate well with protein levels. Therefore, both methods might yield indirect information but only direct analysis of HLA expression on the protein level is capable of appropriate HLA class I quantification.

Thus, the aim of this study was to use a well-established quantitative molecular method [23] for the direct comparison of HLA class I molecules presented by RCC. For this goal we used Edman degradation as a tool to quantify HLA class I molecules isolated by immunoprecipitation. This method should easily reveal quantitative differences between HLA class I presentation on primary tumor, autologous kidney tissue and metastases of RCC and by doing so, predict the success of immunotherapeutic concepts for metastatic RCC.

\section{Methods}

\section{Patients and tumor samples}

Tissue samples from RCC patients were provided by the Clinic for Urology, University of Tübingen, Germany. We acquired tissue from primary RCC tumors, from corresponding normal kidney, and synchronous or metachronous metastases which occurred in contiguous lymph nodes, contralateral kidney or other viscera. Specimens were frozen in liquid nitrogen immediately after surgery and stored at $-80^{\circ} \mathrm{C}$ until further use. In addition, a corresponding vital specimen of tumor tissue was collected as fresh tissue in RPMI and used by the $\mathrm{T}$ cell monitoring group, Department of Immunology, University of Tübingen, for collecting tumor infiltrating lymphocytes (TILs). This study has been approved by the local ethical review board.

\section{Peptide extraction}

Frozen tumor, normal kidney and metastatic tissues were processed as described previously [24,25]. Briefly, peptides were isolated according to standard protocols by immunoprecipitation of HLA molecules from solid tissues using the HLA-A, $-\mathrm{B}$, and $-\mathrm{C}$ specific antibody W6/32 coupled to CNBr-activated Sepharose (Roche Applied Science) followed by acid elution and subsequent ultrafiltration.

\section{Immunohistochemistry for the detection of MHC class I molecules}

For antigen retrieval formaldehyde-fixed $5 \mu \mathrm{m}$ paraffin sections from tumors were heated with $10 \mathrm{mmol} / \mathrm{L}$ citrate buffer ( $\mathrm{pH}$ 6.0) for 5 minutes at $120^{\circ} \mathrm{C}$ followed by incubation with the mouse monoclonal anti-HLA-A/B/C antibody (clone W6/32, ATCC) for $1 \mathrm{~h}$ at room temperature. Subsequently, the sections were incubated with biotinylated anti-mouse-antibodies (Vector Laboratories, Inc., Burlingame, CA) for 30 minutes at room temperature, and a streptavidin-biotin-immunoperoxidase system (Vectastain Elite StreptABC, Vector Laboratories, Inc., Burlingame, CA) followed by DAB (Dako) and counterstained with hematoxylin. As a negative control, isotype-matched IgG were used in place of the primary antibody. Slides were viewed with a Zeiss Axioskop 40 microscope.

\section{Edman degradation}

HLA yield was determined by Edman degradation using a pulsed-liquid protein sequencer Procise 494A (Applied Biosystems) equipped with a special $\mathrm{C}_{18}$ column for phenylthiohydantoin (PTH) amino acid analysis (Spheri-5 PTH $5 \mu \mathrm{m}, 220 \times 2.1 \mathrm{~mm}$; PerkinElmer). Edman degradation chemistry efficiency is determined primarily by two chemical reactions. The first is a phenylisothiocyanate (PITC) coupling reaction to the $\mathrm{N}$-terminus of a protein. PITC reacts with the free amino (NH2) group, resulting in an acid labile phenylthiocarbamyl derivative at the $\mathrm{N}$ terminus of the protein. Subsequently, trifluoroacetic acid (TFA) is introduced to cleave the modified N-terminal amino acid from the protein. After further modification to a more stable phenylthiohydantoin (PTH) derivative, the derivatized amino acid is chromatographed. The PTH amino acid is identified by its unique retention time in the chromatogram. This process is repeated iteratively for each subsequent terminal amino acid of the protein.

With the known N-terminal sequence of the HLA class I molecule it is possible to calculate the yield of HLA in each sample by determining the amount of PTH amino acids over the sequencing cycles. For this study we sequenced and analyzed the first seven amino acids of the HLA class I $\alpha$-chain (GSHSMRY) which are conserved among all human class I molecules. Due to background effects of the abundant amino acids serine and glycine, the contaminating sequence NIVMTQS from Ig kappa chains, and varying yields of the somewhat unstable arginine [23], we focused in particular on the amount of histidine in the third cycle after subtracting the background value of the preceding cycle. Recombinant HLA class I monomers served to verify the reliability of our method. Samples of tumor, normal tissue and metastases acquired from the same patient were always sequenced directly in series, thus avoiding the influence of any day-to-day variation in this nonetheless quite robust analytical method. 
Normalization and statistical analysis

Results of quantitative Edman degradation were normalized according to the HLA yield from $1 \mathrm{~g}$ of tissue. Statistical analysis for significant differences in HLA yields was performed using the unpaired Student's t-test (Graph Pad Prism 5 Software).

\section{Results}

The general outline of the study was to establish a method for direct HLA quantification from lysates of RCC. We performed immunoprecipitation of HLA class I molecules using affinity chromatography and determined the yield of eluted HLA class I molecules by quantitative Edman degradation. Tissues analyzed within this study are shown in Table 1. Quantification was

Table 1 Tissue samples and amounts of immunopurified HLA class I

\begin{tabular}{|c|c|c|c|c|c|c|}
\hline $\begin{array}{l}\text { Tissue } \\
\text { specimen }\end{array}$ & $\begin{array}{l}\text { Tumor (T) } \\
\text { Normal renal } \\
\text { tissue (NK) } \\
\text { Metastasis (M) }\end{array}$ & Type & $\begin{array}{l}\text { Mass } \\
(\mathrm{g})\end{array}$ & TILs & $\begin{array}{l}\text { Edman } \\
\text { results } \\
\text { (pmol) }\end{array}$ & $\begin{array}{c}\text { Average } \\
\text { HLA } \\
\text { amount } \\
\text { (pmol/g) }\end{array}$ \\
\hline RCC399 & $\begin{array}{l}\text { NK } \\
T \\
\text { M (lymph } \\
\text { node) }\end{array}$ & cCRCC & $\begin{array}{c}2.4 \\
13.8 \\
1.0\end{array}$ & yes & $\begin{array}{c}60 \\
1000 \\
40\end{array}$ & $\begin{array}{l}25.0 \\
72.5 \\
40.0\end{array}$ \\
\hline RCC377 & $\begin{array}{l}\text { NK } \\
T \\
\text { M (lymph } \\
\text { node) }\end{array}$ & cCRCC & $\begin{array}{c}4.2 \\
12.7 \\
4.5\end{array}$ & n.d & $\begin{array}{c}500 \\
6000 \\
3500\end{array}$ & $\begin{array}{l}119.0 \\
472.4 \\
777.8\end{array}$ \\
\hline RCC 364 & $\begin{array}{l}\text { NK } \\
T \\
\text { M (lymph } \\
\text { node) }\end{array}$ & cCRCC & $\begin{array}{l}1.2 \\
5.8 \\
0.4\end{array}$ & yes & $\begin{array}{c}10 \\
1000 \\
20\end{array}$ & $\begin{array}{c}8.3 \\
172.4 \\
50.0\end{array}$ \\
\hline Rcc343 & $\begin{array}{l}\text { NK } \\
\mathrm{T} \\
\mathrm{M} \text { (liver) }\end{array}$ & cCRCC & $\begin{array}{l}3.2 \\
2.1 \\
3.2\end{array}$ & n.d & $\begin{array}{c}20 \\
200 \\
1400\end{array}$ & $\begin{array}{c}6.3 \\
95.2 \\
437.5\end{array}$ \\
\hline RCC70 & $\begin{array}{l}\text { NK } \\
T \\
\text { M (lymph } \\
\text { node) }\end{array}$ & cCRCC & $\begin{array}{l}4.4 \\
8.3 \\
2.6\end{array}$ & n.d. & $\begin{array}{c}300 \\
3200 \\
200\end{array}$ & $\begin{array}{c}68.2 \\
385.5 \\
76.9\end{array}$ \\
\hline RCC307 & $\begin{array}{l}\text { NK } \\
\mathrm{T}\end{array}$ & $\mathrm{pRCC}$ & $\begin{array}{l}2.7 \\
1.6\end{array}$ & n.d. & $\begin{array}{l}200 \\
400\end{array}$ & $\begin{array}{c}74.1 \\
250.0\end{array}$ \\
\hline RCC211 & $\begin{array}{l}\text { NK } \\
\mathrm{T}\end{array}$ & $\mathrm{pRCC}$ & $\begin{array}{c}0.4 \\
20.7\end{array}$ & n.d. & $\begin{array}{c}10 \\
2100\end{array}$ & $\begin{array}{c}25.0 \\
101.4\end{array}$ \\
\hline RCC193 & $\begin{array}{l}\text { NK } \\
\mathrm{T}\end{array}$ & $\mathrm{cCRCC}$ & $\begin{array}{l}2.4 \\
4.7\end{array}$ & n.d. & $\begin{array}{l}500 \\
850\end{array}$ & $\begin{array}{l}208.3 \\
180.9\end{array}$ \\
\hline RCC131 & $\begin{array}{l}\text { NK } \\
\mathrm{T}\end{array}$ & cCRCC & $\begin{array}{c}6.5 \\
11.5\end{array}$ & n.d. & $\begin{array}{l}400 \\
300\end{array}$ & $\begin{array}{l}61.5 \\
26.1\end{array}$ \\
\hline RCC121 & $\begin{array}{l}\text { NK } \\
\mathrm{T}\end{array}$ & cCRCC & $\begin{array}{c}6.2 \\
10.4\end{array}$ & no & $\begin{array}{l}500 \\
460\end{array}$ & $\begin{array}{l}44.2 \\
80.6\end{array}$ \\
\hline RCC119 & $\begin{array}{l}\text { NK } \\
\mathrm{T}\end{array}$ & cCRCC & $\begin{array}{l}8.9 \\
7.8\end{array}$ & yes & $\begin{array}{l}440 \\
560\end{array}$ & $\begin{array}{l}49.4 \\
71.8\end{array}$ \\
\hline RCC 110 & $\begin{array}{l}\text { NK } \\
\mathrm{T}\end{array}$ & chRCC & $\begin{array}{c}13.0 \\
7.0\end{array}$ & yes & $\begin{array}{l}1700 \\
3900\end{array}$ & $\begin{array}{l}130.8 \\
557.1\end{array}$ \\
\hline RCC100 & $\begin{array}{l}\text { NK } \\
\mathrm{T}\end{array}$ & $\mathrm{CCRCC}$ & $\begin{array}{c}12.6 \\
8.0\end{array}$ & no & $\begin{array}{l}1400 \\
1200\end{array}$ & $\begin{array}{l}111.1 \\
150.0\end{array}$ \\
\hline RCC99 & NK T & $\mathrm{CCRCC}$ & $\begin{array}{c}12.4 \\
7.7\end{array}$ & no & $\begin{array}{l}1500 \\
1300\end{array}$ & $\begin{array}{l}121.0 \\
168.8\end{array}$ \\
\hline RCC81 & $\begin{array}{l}\text { NK } \\
\mathrm{T}\end{array}$ & chRCC & $\begin{array}{l}10.0 \\
18.0\end{array}$ & no & $\begin{array}{l}1400 \\
1800\end{array}$ & $\begin{array}{l}100.0 \\
140.0\end{array}$ \\
\hline
\end{tabular}

Table 1 Tissue samples and amounts of immunopurified HLA class I (Continued)

\begin{tabular}{|c|c|c|c|c|c|c|}
\hline RCC76 & $\begin{array}{l}\mathrm{NK} \\
\mathrm{T}\end{array}$ & cCRCC & $\begin{array}{c}6.2 \\
12.8\end{array}$ & n.d. & $\begin{array}{l}1200 \\
2600\end{array}$ & $\begin{array}{c}193.5 \\
20.3\end{array}$ \\
\hline RCC71 & $\begin{array}{l}\mathrm{NK} \\
\mathrm{T}\end{array}$ & cCRCC & $\begin{array}{l}9.0 \\
7.0\end{array}$ & n.d. & $\begin{array}{c}10 \\
3000\end{array}$ & $\begin{array}{c}1.1 \\
428.6\end{array}$ \\
\hline RCC58 & $\begin{array}{l}\text { NK } \\
\mathrm{T}\end{array}$ & cCRCC & $\begin{array}{l}7.6 \\
7.2\end{array}$ & no & $\begin{array}{l}2000 \\
2400\end{array}$ & $\begin{array}{l}263.2 \\
333.3\end{array}$ \\
\hline RCC57 & $\begin{array}{l}\text { NK } \\
\mathrm{T}\end{array}$ & n.d. & $\begin{array}{l}6.8 \\
8.7\end{array}$ & yes & $\begin{array}{l}1900 \\
2500\end{array}$ & $\begin{array}{l}279.4 \\
287.4\end{array}$ \\
\hline RCC53 & $\begin{array}{l}\text { NK } \\
\mathrm{T}\end{array}$ & n.d. & $\begin{array}{l}6.9 \\
6.2\end{array}$ & n.d. & $\begin{array}{l}1300 \\
1900\end{array}$ & $\begin{array}{l}188.4 \\
306.5\end{array}$ \\
\hline RCC52 & $\begin{array}{l}\text { NK } \\
\mathrm{T}\end{array}$ & cCRCC & $\begin{array}{l}7.4 \\
7.0\end{array}$ & n.d. & $\begin{array}{c}100 \\
2000\end{array}$ & $\begin{array}{c}13.5 \\
285.7\end{array}$ \\
\hline RCC51 & $\begin{array}{l}\text { NK } \\
\mathrm{T}\end{array}$ & chRCC & $\begin{array}{l}7.0 \\
7.8\end{array}$ & n.d. & $\begin{array}{l}2100 \\
2000\end{array}$ & $\begin{array}{l}300.0 \\
256.4\end{array}$ \\
\hline RCC49 & $\begin{array}{l}\text { NK } \\
\mathrm{T}\end{array}$ & n.d. & $\begin{array}{l}7.0 \\
8.8\end{array}$ & n.d. & $\begin{array}{l}1300 \\
2900\end{array}$ & $\begin{array}{l}185.7 \\
329.5\end{array}$ \\
\hline RCC46 & $\begin{array}{l}\text { NK } \\
\mathrm{T}\end{array}$ & n.d. & $\begin{array}{l}7.6 \\
9.3\end{array}$ & n.d. & $\begin{array}{l}400 \\
1500\end{array}$ & $\begin{array}{c}52.6 \\
161.3\end{array}$ \\
\hline RCC173 & $\begin{array}{l}\text { NK } \\
\text { M } \\
\text { (contralateral } \\
\text { k.) }\end{array}$ & cCRCC & $\begin{array}{l}5,0 \\
5,1\end{array}$ & n.d. & $\begin{array}{c}40 \\
240\end{array}$ & $\begin{array}{c}8.0 \\
47.1\end{array}$ \\
\hline RCC249 & $\mathrm{T}$ & chRCC & 2.6 & n.d. & 80 & 30.8 \\
\hline RCC231 & $\mathrm{T}$ & $\mathrm{pRCC}$ & 6.3 & n.d. & 380 & 60.3 \\
\hline $\mathrm{RCC} 226$ & $\mathrm{~T}$ & cCRCC & 6.8 & n.d. & 250 & 36.8 \\
\hline RCC195 & $\mathrm{T}$ & cCRCC & 60.0 & n.d. & 50 & 0.8 \\
\hline RCC130 & $\mathrm{T}$ & cCRCC & 6.0 & no & 1100 & 183.3 \\
\hline $\mathrm{RCC} 125$ & $\mathrm{~T}$ & cCRCC & $\begin{array}{c}15.5 \\
8.1\end{array}$ & n.d. & 400 & 25.8 \\
\hline RCC 116 & $\mathrm{~T}$ & cCRCC & 15.8 & yes & 2380 & 150.6 \\
\hline RCC 115 & $\mathrm{~T}$ & cCRCC & 26.0 & yes & 12900 & 496.2 \\
\hline RCC113 & $\mathrm{T}$ & cCRCC & 10.1 & n.d. & 200 & 19.8 \\
\hline RCC108 & $\mathrm{T}$ & $\mathrm{pRCC}$ & 30.0 & yes & 1500 & 50.0 \\
\hline RCC103 & $\mathrm{T}$ & chRCC & 10.0 & yes & 4400 & 440.0 \\
\hline RCC101 & $\mathrm{T}$ & cCRCC & 7.5 & yes & 800 & 106.7 \\
\hline RCC98 & $\mathrm{T}$ & cCRCC & 21.1 & n.d. & 2100 & 99.5 \\
\hline RCC90 & $\mathrm{T}$ & cCRCC & 20.0 & n.d. & 10200 & 510.0 \\
\hline RCC75 & $\mathrm{T}$ & $\mathrm{pRCC}$ & 16.0 & n.d. & 2200 & 137.5 \\
\hline RCC73 & $\mathrm{T}$ & cCRCC & 10.0 & n.d. & 1300 & 130.0 \\
\hline RCC68 & $\mathrm{T}$ & cCRCC & 20.0 & yes & 2500 & 125.0 \\
\hline RCC395 & $\begin{array}{l}\text { M (lymph } \\
\text { node) }\end{array}$ & cCRCC & 1.4 & n.d. & 50 & 35.7 \\
\hline RCC333 & M (pancreas) & cCRCC & 10.9 & yes & 3000 & 275.2 \\
\hline RCC328 & $\begin{array}{l}\text { M } \\
\text { (contralateral k.) }\end{array}$ & cCRCC & 1.5 & n.d. & 300 & 200.0 \\
\hline RCC112 & $\begin{array}{l}\text { M (adrenal } \\
\text { gland) }\end{array}$ & cCRCC & 2.5 & n.d. & 700 & 280.0 \\
\hline $\mathrm{RCC} 126$ & NK & cCRCC & 8.9 & yes & 200 & 22.5 \\
\hline
\end{tabular}

Total and normalized HLA yields of all tissue samples analyzed in this study. Weight, histological subtype and information about present TILs are indicated for each examined RCC (tumor, normal tissue and metastases). HLA typing was carried out by the Institute for Clinical and Experimental Transfusion Medicine and histologic classification was performed by the Department of Pathology, University of Tübingen, Germany. T, tumor; NK, normal kidney; M, metastasis; n.d., not determined; ccRCC, clear cell renal cell carcinoma; pRCC, papillary renal call carcinoma; chRCC, chromophilic renal cell carcinoma; no, no TILs detected; yes, TILs detected. 
carried out for a total of 47 RCC caucasian patients. From 5 RCC patients we could acquire triplet tissue samples from tumor, corresponding kidney tissue and metastases. In addition, 19 autologous pairs of tumor and normal renal tissue could be analyzed in this study. From one patient we obtained only normal tissue and a distant metastasis from contralateral kidney. In addition, 17 single primary tumors, 4 single metastases and 1 single normal tissue were analyzed. All examined tissues were processed with identical methods and the same protein sequencer.

HLA yield appeared to be very heterogeneous with total HLA class I amounts ranging from 10 to 12900 pmol respectively from 0.8 to $777.8 \mathrm{pmol} / \mathrm{g}$ for normalized HLA yield (Table 1).

\section{Overall quantitative comparison}

Table 1 shows the overall HLA yield determined by Edman degradation and the normalized HLA yield in $\mathrm{pmol} / \mathrm{g}$. For statistical analyses we used unpaired Student's t-tests to identify significant differences in HLA yield from different tissues. Overall comparison between tumor, normal tissue and metastases of all 47 analyzed RCC samples is shown in Figure 1A. The mean amount of HLA class I was $197.8 \pm 24.6 \mathrm{pmol} / \mathrm{g}$ recovered from tumor tissue $(\mathrm{n}=40), 102.3 \pm 17.9 \mathrm{pmol} / \mathrm{g}$ from normal kidney tissue $(\mathrm{n}=26)$ and $222.0 \pm 75.4 \mathrm{pmol} / \mathrm{g}$ from metastases $(n=10)$. Significant differences in HLA yield were observed for the comparison of tumor and normal tissue $(\mathrm{p}=0.0062)$ as well as for metastases and normal tissue $(\mathrm{p}=0.0337)$. The overall comparison clearly showed an increased yield of HLA class I from tumor and metastases of RCC compared to normal kidney tissue. There was also a slight increase of HLA yield on metastases compared to tumor tissue but below the level of statistical significance $(\mathrm{p}=0.69)$.

Looking at the differences between tumor, normal tissue and metastases in the autologous setting (i.e., samples acquired from the same individual) to achieve a direct comparison of the HLA yield (Figure 1B), we determined the mean amount of HLA class I at $222.2 \pm$ $29.6 \mathrm{pmol} / \mathrm{g}$ on tumor tissue $(\mathrm{n}=24), 109.6 \pm$ $18.6 \mathrm{pmol} / \mathrm{g}$ on normal kidney tissue $(\mathrm{n}=24)$ and 276.4 $\pm 145.7 \mathrm{pmol} / \mathrm{g}$ on metastases $(\mathrm{n}=5)$. Again, statistically significant differences in HLA yield were detected for the comparison between tumor and normal tissue $(\mathrm{p}=$ 0.0023 ) as well as for the comparison between metastases and normal tissue $(\mathrm{p}=0.0329)$. Comparison between tumor and metastases showed again a slight but non-significant increase in HLA yield from metastases, due to low sample numbers. This direct autologous comparison confirmed the results of the overall comparison, demonstrating an increased amount of
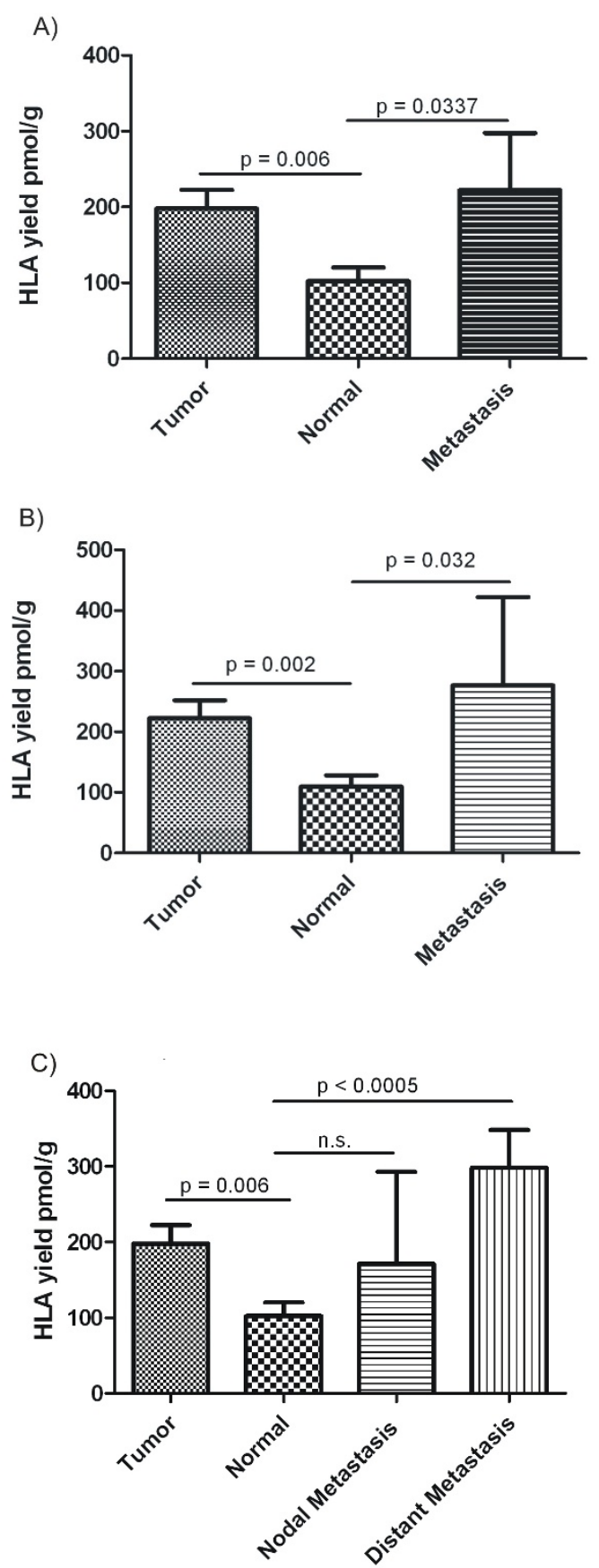

Figure 1 HLA yields from different tissues were normalized to $\mathbf{1} \mathbf{g}$ of tissue. The mean value of the normalized HLA yield of the respective tissue type is given plus standard error of the mean (SEM). Statistical significance of the differences between tissues is reflected in $\mathrm{p}$ values determined by the Student's t-test and indicated in the histogram. Amounts of immunopurified HLA class I compared between: A) Primary tumors (Tumor), normal tissues (Normal) and metastases of all analyzed tissue samples (overall comparison). B) Primary tumor, corresponding normal tissue and metastases obtained from the same patient (autologous comparison). C) Primary tumor, normal tissue, lymph node metastases and distant metastases of all analyzed tissue samples. 
HLA class I on tumor and metastases of RCC compared to normal kidney tissue.

\section{Differences between local lymph node metastases and distant metastases of RCC}

In order to distinguish between HLA quantities recovered from lymph node metastases and distant metastases (derived from pancreas, liver, adrenal gland and controlateral kidney), we compared tumor and normal kidney tissue to lymph node metastases and distant metastases, separately (Figure 1C). The mean amount of HLA class I detected was $171.3 \pm 121.5 \mathrm{pmol} / \mathrm{g}$ from local lymph node metastases $(n=6)$ and $298.2 \pm 49.9$ $\mathrm{pmol} / \mathrm{g}$ on distant metastases $(\mathrm{n}=4)$. Higher HLA yield from distant metastases compared to normal tissue showed a statistical significance $(\mathrm{p}=0.0005)$, whereas the comparison between normal tissue and lymph node metastases could not reach a level of significance. Thus HLA presentation on distant metastases of RCCs appears to be higher than on lymph node metastases.

\section{Impact of tumor infiltrating lymphocytes on the HLA yield of RCC}

In order to rule out the possibility that tumor infiltrating lymphocytes (TILs) have a strong impact on quantitative HLA analysis by Edman degradation, we compared primary RCCs from which TILs could be cultured with tumors from which no TILs could be isolated and cultured (Figure 2). The mean amount of HLA class I was $230.0 \pm 55.9 \mathrm{pmol} / \mathrm{g}$ recovered from $\mathrm{RCC}$ with

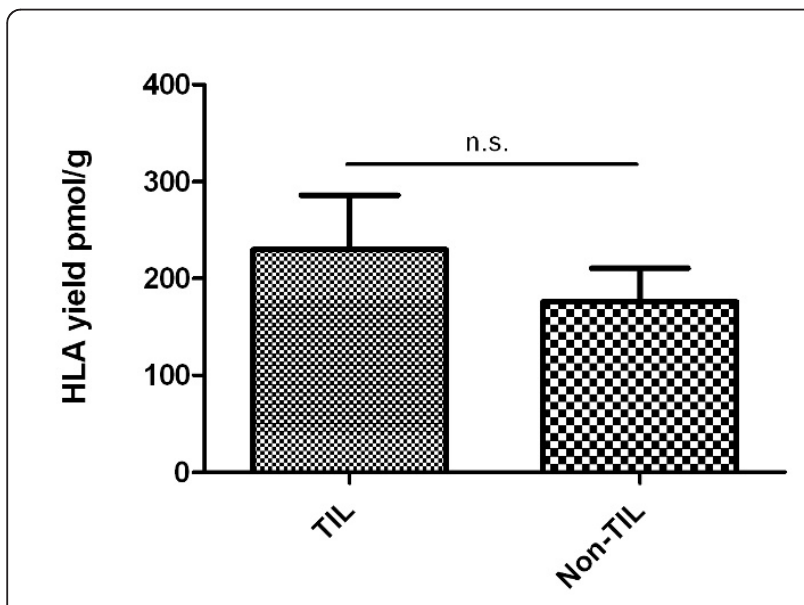

Figure 2 Comparison TILs vs. no TILs. Amounts of immunopurified HLA class I compared between primary tumors containing TILs and tumor tissue without TILs. Yields were normalized to $1 \mathrm{~g}$ of tissue. The mean value of the normalized $\mathrm{HLA}$ yield of the respective tissue type is given plus standard error of the mean (SEM). Statistical significance of the differences between tissues is reflected in $p$ values determined by the Student's t-test and indicated in the histogram.
TILs $(\mathrm{n}=11)$ compared to $176.0 \pm 34.6 \mathrm{pmol} / \mathrm{g}$ from tumors without TILs $(n=6)$. This comparison shows that the HLA amount in tumors containing TILs is slightly higher than in tumors without TILs. However, statistical analysis showed no significance; the $\mathrm{p}$ value of 0.51 suggests a nearly identical HLA yield on both tumor groups.

\section{Immunohistochemical analysis of HLA class I expression}

We performed immunohistochemistry as a complementary method to visualize HLA class I expression in different tissues of our patients. Figure 3 shows exemplarily our findings in RCC377, revealing an abundant HLA class I expression in a lymph node metastasis as well as a stronger expression in primary tumor cells in comparison to normal kidney tissue. Within the lymph node metastasis, epithelial cells and immune cells contribute to HLA class I expression but tumor cells are also intensely stained.

\section{Discussion}

\section{Edman degradation for quantitative HLA analysis}

Although other techniques have in the meantime surpassed Edman chemistry in sensitivity, cost, and use for routine protein characterization, automated Edman degradation remains the most effective tool for obtaining $\mathrm{N}$-terminal amino acid sequence information, and represents a reliable quantitative technique in its routine application [26]. Therefore we chose Edman degradation with the intention of establishing a method for direct quantitative analysis of HLA molecules immunopurified from RCC. To our knowledge this is the first study comparing HLA yield on tumor, normal tissue and metastases of RCC using direct quantification. Previous studies used indirect methods, such as immunofluorescence, or analysed the HLA class I expression on mRNA level [20,27,28].

Considering intrinsic effects of automated Edman degradation chemistry, such as inefficiencies in the coupling and cleavage reactions as well as different recoveries of PTH amino acids, we sequenced and analyzed the first seven amino acids of the HLA class I $\alpha$-chain (GSHSMRY), focusing especially on quantitation of histidine in the third cycle. Raw values were neither corrected for repetitive yields (for the instruments operating in most laboratories, a 92-94\% overall repetitive yield is considered acceptable [26]) nor for initial yields or PTH amino acid recoveries [23]. The first monitoring measurements with known yields of recombinant HLA class I monomers evinced histidine in sequence position 3 as most reliable parameter for the overall HLA amount of the analyzed sample. Other authors reported of large errors in the calculated amount of peptides when several different amino acids 


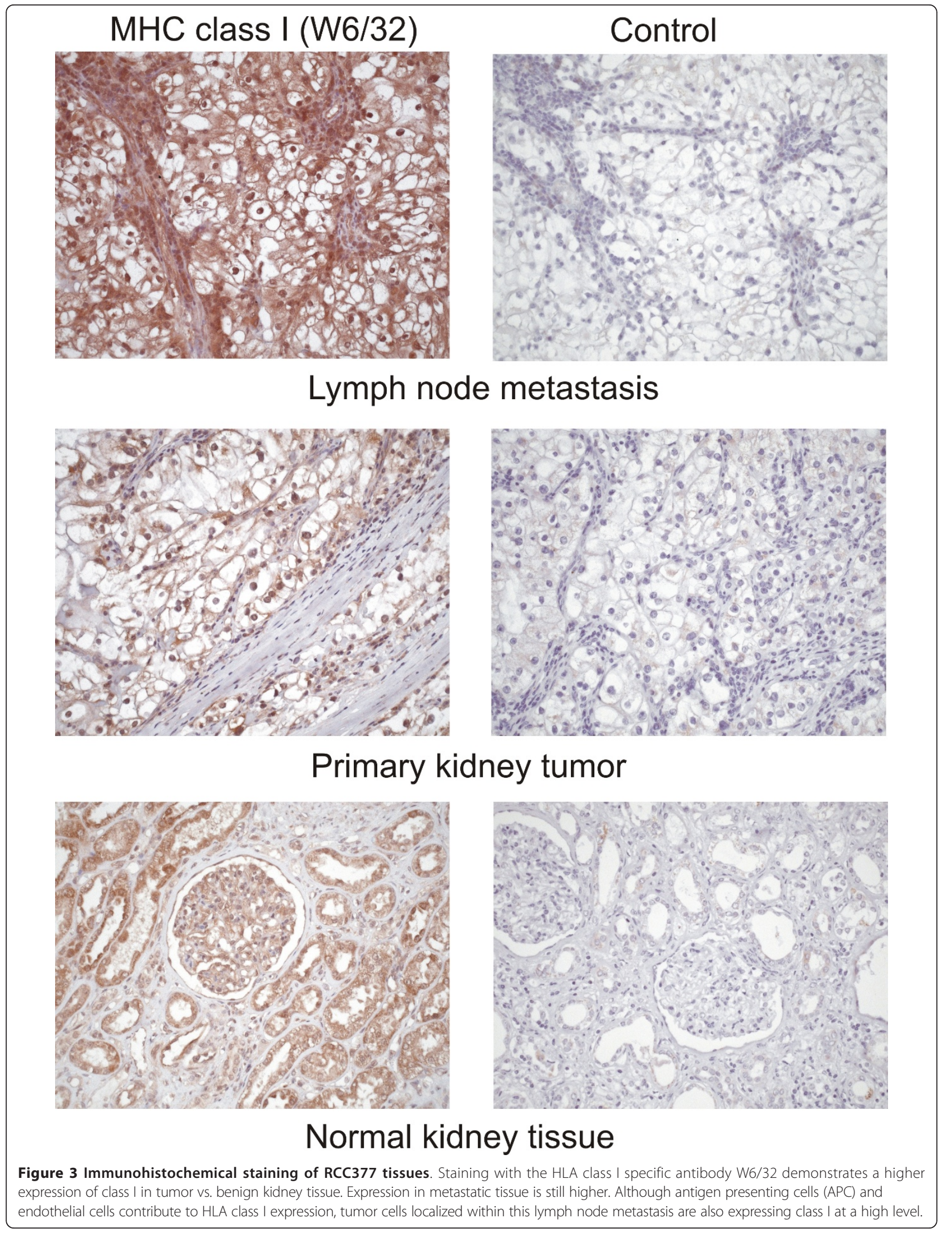


were used for repetitive and initial yield calculations $[26,29]$.

The aim of this study was not to establish a method for determining the absolute amount of HLA class I molecules on the cell surface, but to obtain relative amounts that are comparable between different types of tissues. A study of the Edman Sequencing Research Group (ESRG) showed that the relative amounts comparing two different samples were highly accurate, the average error being $6.8 \%$ [26].

Thus Edman degradation proved to be an appropriate method for direct quantitative comparison of HLA class I molecules immunopurified from tumor, normal tissue and metastases of RCC patients. We have to emphasize, however, that rather large samples are required with respect to the sensitivity of Edman sequencers. Our study included tissues of far more than $2 \mathrm{~g}$ in most cases; the need for a big sample size prevented the analysis of larger cohorts.

\section{Results of quantitative HLA analysis}

The presentation of HLA class I antigens on tumor cells represents a major factor in determining the success and clinical outcome of immunotherapeutic concepts aimed at increasing specific anti-tumor activity of CTLs. In order to predict the success of immunotherapeutic approaches for metastatic RCC, it was decided to compare HLA class I presentation on primary tumor, autologous normal kidney tissue and metastases of renal cell carcinoma. We performed this comparison on different levels, including local and distant metastases. To our knowledge this is the first study determining HLA class I yield directly on the protein level from RCCs and metastatic tissue.

The HLA yield was found in most cases to be dependent on the tissue mass (Table 1). Low amounts of HLA class I recovered from bulky tumors with a mass up to $60 \mathrm{~g}$ are presumably due to necrotic decay or stromal invasion of these tumors in vivo.

The overall comparison of all 47 analyzed tissue samples (Figure 1) as well as the direct comparison of 24 autologous pairs of tumor and normal tissue (Figure 2) showed a significantly higher yield of HLA class I from tumor than normal tissue.

It has to be mentioned that tumors represent heterogeneous tissues which contain different subsets of cells. Although RCC is expected to be more homogenous than, for example, colon carcinoma, the tumors analyzed in this study might harbor endothelial cells and - most important - immune cells that could distort HLA quantification because of their high HLA expression. To demonstrate that a greater HLA yield from the tumors was indeed due to a higher HLA class I amount on tumor cells and not to tumor infiltrating lymphocytes (TILs), which could be found in $70 \%$ of all renal cell carcinomas (Table 1 and C. Gouttefangeas, unpublished), we compared primary RCCs from which TILs could be cultured with tumors from which no TILs could be isolated (Figure 2). Although we observed a tendency of TIL-containing tumors to yield slightly more HLA class I molecules than the TIL-free samples, the differences were not statistically significant $(\mathrm{p}=0.51)$ and thus much smaller than the differences between tumor and normal tissue. From these data there seems to be no major impact of TILs on the results of quantitative HLA analysis in RCC tumors. On the other hand, we cannot rule out completely that endothelial cells or antigen presenting cells $[20,21]$ contribute to the enhanced recovery of HLA molecules from tumor tissue and in particular from lymph node metastases. Immunohistochemical staining of tissues, as exemplarily shown in RCC 377 , confirms abundant expression of HLA class I on the surface of tumor cells but also endothelial and immune cells. Figure 3 gives an impression of HLA density on the different subsets of cell types. As outlined above, however, immunhistochemistry as a semi-quantitative method gives information on one layer of tissue only.

Recent reports have described a total or partial loss of HLA class I for nearly all types of tumors $[18,30]$. HLA class I downregulation or complete loss was observed in $10-50 \%$ of melanomas, breast, lung, colorectal, cervix and prostate cancers [19]. In case of RCC, downregulation and loss of HLA class I has also been described: The amount of HLA negative tumors was determined to be up to $37.8 \%$ and was correlated with lower 5-year survival rates [20]. On the other hand, higher HLA expression in RCC compared to normal kidney tissue has been reported as well [22,31]. The individual analysis of our study indicates a slight HLA downregulation on tumor tissue compared to normal tissue for only 5 of 24 tumors and normal tissue pairs $(20.8 \%)$ (Table 1), whereas for most of the tumor tissues considerably higher HLA class I amounts were quantified. There was no significant difference in HLA presentation on different subtypes of RCCs investigated in this study.

Since T-cell based immunotherapy is not expected to clear bulky tumor masses, many clinical applications focus on the stage of minimal residual disease. To combat micrometastases remaining after dissection of the primary tumor, the metastases must express certain HLA levels and present tumor-associated peptides. In a recent report we confirmed that tumor-associated HLA ligands are indeed shared between primary tumors and metastases [32]. Here, we performed a quantitative comparison of HLA class I molecules immunopurified from 
metastases, primary tumors, and normal tissues (Figures 1A, B) and detected significantly higher HLA amounts on metastatic tissue compared to normal kidney tissue. HLA class I yield from metastatic tissue was slightly higher than from tumor tissue, but beyond the level of significance. Contrary to the expectation that lymph node metastases, due to their higher amount of immune cells, should contain more HLA class I molecules, the comparison between lymph node metastases and distant metastases (Figure $1 \mathrm{C}$ ) revealed a significantly higher amount of HLA on distant metastases than on normal tissue and lymph node metastases. These findings are in contrast to reports of HLA downregulation or loss even stronger in metastases than in primary tumors [33]. However, HLA loss rates vary between different tumor entities [34] and there are only few reports on HLA expression in distant metastases of RCC. Numerous reports have correlated tumor progression with downregulation or complete loss of HLA $[16,21,35]$, for example in metastatic melanoma a high HLA class I amount (on metastases) correlated with regression whereas a low HLA amount correlated with progression under therapy [16]. These facts and our data hold promise for the success of immunotherapeutic strategies also against metastatic RCC.

\section{Conclusion}

The aim of our study was to establish a direct method for quantitative analysis of HLA class I molecules immunopurified from tumor, normal tissue, and metastases of RCC. Edman degradation appears to be a feasible, effective and reliable method for performing quantitative direct comparisons of samples of sufficient size. Our results may contradict other reports, but they do provide an impulse for improving the effectiveness of current and future immunotherapeutic concepts for metastatic RCC. Due to the limited amount of samples analyzed and the heterogeneity of the individual HLA yields our results cannot be generalized at present.

\section{Abbreviations \\ CNBr: Cyanogen bromide; CTL: Cytotoxic T lymphocyte; ESRG: Edman Sequencing Research Group; HLA: Human leukocyte antigen; IFN Interferon; IL: Interleukin; PITC: Phenylisothiocyanate; PTH: Phenylthiohydantoin; RCC: Renal cell carcinoma; ccRCC: Clear cell renal cell carcinoma; chRCC: Chromophobe renal cell carcinoma; pRCC: Papillary renal cell carcinoma; RNA: Ribonucleic acid; TFA: Trifluoroacetic acid; TILs: Tumor infiltrating lymphocytes}

\section{Acknowledgements}

We thank Lynne Yakes for critically reading the manuscript as well as Andreas Weinzierl, Margret Müller, Tobias Krüger, Christian Reichle, Anna Missiou, Björn Krämer and Cecile Gouttefangeas for contributing data. Support

This work was supported by the Deutsche Forschungsgemeinschaft (DFG, SFB 685, GK 794) and the European Union (Cancer Immunotherapy, LSHC-CT-2006, 518234)

\section{Author details}

'Department of Immunology, Institute for Cell Biology, University of Tübingen, Germany. ${ }^{2}$ Clinic for Urology, University of Tübingen, Germany ${ }^{3}$ Department of Hematology Oncology, University of Freiburg, Germany.

${ }^{4}$ Department of Molecular Pathology, University of Tübingen, Germany.

\section{Authors' contributions}

JS carried out the immunoprecipitation and Edman analysis and drafted the manuscript. NS carried out the statistical analysis. JH and AS provided the tumor, normal and metastasis tissue. KK performed immunohistochemical stainings. SS and HGR participated in the design of the study and its coordination. All authors read and approved the final manuscript.

\section{Competing interests}

The authors declare that they have no competing interests.

Received: 11 September 2010 Accepted: 20 January 2011

Published: 20 January 2011

\section{References}

1. Vogelzang NJ, Stadler WM: Kidney cancer. Lancet 1998 352(9141):1691-1696.

2. Ravaud A, Wallerand H, Culine S, Bernhard JC, Fergelot P, Bensalah K, Patard JJ: Update on the medical treatment of metastatic renal cell carcinoma. Eur Urol 2008, 54(2):315-325

3. Tamaskar I, Pili R: Update on novel agents in renal cell carcinoma. Expert Rev Anticancer Ther 2009, 9(12):1817-1827.

4. Coppin C, Porzsolt F, Awa A, Kumpf J, Coldman A, Wilt T: Immunotherapy for advanced renal cell cancer. Cochrane Database Syst Rev 2005, , 1: CD001425.

5. Schendel DJ: Dendritic cell vaccine strategies for renal cell carcinoma. Expert Opin Biol Ther 2007, 7(2):221-232.

6. Uemura H, Fujimoto $K$, Tanaka M, Yoshikawa M, Hirao Y, Uejima S, Yoshikawa K, Itoh K: A phase I trial of vaccination of CA9-derived peptides for HLA-A24-positive patients with cytokine-refractory metastatic renal cell carcinoma. Clin Cancer Res 2006, 12(6):1768-1775.

7. Suekane S, Nishitani M, Noguchi M, Komohara Y, Kokubu T, Naitoh M, Honma S, Yamada A, Itoh K, Matsuoka K, et al: Phase I trial of personalized peptide vaccination for cytokine-refractory metastatic renal cell carcinoma patients. Cancer Sci 2007, 98(12):1965-1968.

8. Van Poppel H, Joniau S, Van Gool SW: Vaccine therapy in patients with renal cell carcinoma. Eur Urol 2009, 55(6):1333-1342

9. Brossart P: Dendritic cells in vaccination therapies of malignant diseases. Transfus Apher Sci 2002, 27(2):183-186.

10. Kubler H, Vieweg J: Vaccines in renal cell carcinoma. Semin Oncol 2006, 33(5):614-624

11. Wierecky J, Muller MR, Wirths S, Halder-Oehler E, Dorfel D, Schmidt SM, Hantschel M, Brugger W, Schroder S, Horger MS, et al: Immunologic and clinical responses after vaccinations with peptide-pulsed dendritic cells in metastatic renal cancer patients. Cancer Res 2006, 66(11):5910-5918.

12. Garcia KC, Degano M, Pease LR, Huang M, Peterson PA, Teyton L, Wilson IA: Structural basis of plasticity in $T$ cell receptor recognition of a self peptide-MHC antigen. Science 1998, 279(5354):1166-1172.

13. Kageyama S, Tsomides TJ, Sykulev Y, Eisen HN: Variations in the number of peptide-MHC class I complexes required to activate cytotoxic T cell responses. J Immunol 1995, 154(2):567-576.

14. Chang CC, Ferrone S: Immune selective pressure and HLA class I antigen defects in malignant lesions. Cancer Immunol Immunother 2007, 56(2):227-236

15. Garrido F, Algarra I: MHC antigens and tumor escape from immune surveillance. Adv Cancer Res 2001, 83:117-158.

16. Aptsiauri N, Carretero R, Garcia-Lora A, Real LM, Cabrera T, Garrido F: Regressing and progressing metastatic lesions: resistance to immunotherapy is predetermined by irreversible HLA class I antigen alterations. Cancer Immunol Immunother 2008, 57(11):1727-1733.

17. Aptsiauri N, Cabrera T, Garcia-Lora A, Lopez-Nevot MA, Ruiz-Cabello F, Garrido F: MHC class I antigens and immune surveillance in transformed cells. Int Rev Cytol 2007, 256:139-189.

18. Rolland P, Deen S, Scott I, Durrant L, Spendlove I: Human leukocyte antigen class I antigen expression is an independent prognostic factor in ovarian cancer. Clin Cancer Res 2007, 13(12):3591-3596. 
19. Seliger B, Cabrera T, Garrido F, Ferrone S: HLA class I antigen abnormalities and immune escape by malignant cells. Semin Cancer Biol 2002, 12(1):3-13.

20. Kitamura H, Honma I, Torigoe T, Asanuma H, Sato N, Tsukamoto T: Downregulation of HLA class I antigen is an independent prognostic factor for clear cell renal cell carcinoma. J Urol 2007, 177(4):1269-1272, discussion 1272.

21. Kitamura H, Torigoe $T$, Honma I, Sato E, Asanuma H, Hirohashi $Y$, Sato $N$ Tsukamoto T: Effect of human leukocyte antigen class I expression of tumor cells on outcome of intravesical instillation of bacillus calmetteguerin immunotherapy for bladder cancer. Clin Cancer Res 2006, 12(15):4641-4644

22. Saenz-Lopez P, Gouttefangeas C, Hennenlotter J, Concha A, Maleno I, RuizCabello F, Cozar JM, Tallada M, Stenzl A, Rammensee HG, et al: Higher HLA class I expression in renal cell carcinoma than in autologous normal tissue. Tissue Antigens 75(2):110-118.

23. Stevanovic S, Jung G: Multiple sequence analysis: pool sequencing of synthetic and natural peptide libraries. Anal Biochem 1993, 212(1):212-220.

24. Falk K, Rotzschke O, Stevanovic S, Jung G, Rammensee HG: Allele-specific motifs revealed by sequencing of self-peptides eluted from $\mathrm{MHC}$ molecules. Nature 1991, 351(6324):290-296.

25. Weinzierl AO, Maurer D, Altenberend F, Schneiderhan-Marra N, Klingel K, Schoor O, Wernet D, Joos T, Rammensee HG, Stevanovic S: A cryptic vascular endothelial growth factor T-cell epitope: identification and characterization by mass spectrometry and T-cell assays. Cancer Res 2008 68(7):2447-2454

26. Brune DC, Hampton B, Kobayashi R, Leone JW, Linse KD, Pohl J, Thoma RS, Denslow ND: ABRF ESRG 2006 study: Edman sequencing as a method for polypeptide quantitation. J Biomol Tech 2007, 18(5):306-320.

27. Atkins D, Ferrone S, Schmahl GE, Storkel S, Seliger B: Down-regulation of HLA class I antigen processing molecules: an immune escape mechanism of renal cell carcinoma? J Urol 2004, 171(2 Pt 1):885-889.

28. Ibrahim EC, Allory Y, Commo F, Gattegno B, Callard P, Paul P: Altered pattern of major histocompatibility complex expression in renal carcinoma: tumor-specific expression of the nonclassical human leukocyte antigen-G molecule is restricted to clear cell carcinoma while up-regulation of other major histocompatibility complex antigens is primarily distributed in all subtypes of renal carcinoma. Am J Pathol 2003, 162(2):501-508

29. Smithies O, Gibson D, Fanning EM, Goodfliesh RM, Gilman JG, Ballantyne DL: Quantitative procedures for use with the Edman-Begg sequenator. Partial sequences of two unusual immunoglobulin light chains, Rzf and Sac. Biochemistry 1971, 10(26):4912-4921.

30. Watson NF, Ramage JM, Madjd Z, Spendlove I, Ellis IO, Scholefield JH, Durrant LG: Immunosurveillance is active in colorectal cancer as downregulation but not complete loss of MHC class I expression correlates with a poor prognosis. Int J Cancer 2006, 118(1):6-10.

31. Romero JM, Aptsiauri N, Vazquez F, Cozar JM, Canton J, Cabrera T, Tallada M, Garrido F, Ruiz-Cabello F: Analysis of the expression of HLA class I, proinflammatory cytokines and chemokines in primary tumors from patients with localized and metastatic renal cell carcinoma. Tissue Antigens 2006, 68(4):303-310.

32. Stickel JS, Weinzierl AO, Hillen N, Drews O, Schuler MM, Hennenlotter J, Wernet D, Muller CA, Stenzl A, Rammensee HG, et al: HLA ligand profiles of primary renal cell carcinoma maintained in metastases. Cancer Immunol Immunother 2009, 58(9):1407-1417.

33. Lopez-Nevot MA, Esteban F, Ferron A, Gutierrez J, Oliva MR, Romero C, Huelin C, Ruiz-Cabello F, Garrido F: HLA class I gene expression on human primary tumours and autologous metastases: demonstration of selective losses of HLA antigens on colorectal, gastric and laryngeal carcinomas. $\mathrm{Br} J$ Cancer 1989, 59(2):221-226.
34. Blades RA, Keating PJ, McWilliam LJ, George NJ, Stern PL: Loss of HLA class I expression in prostate cancer: implications for immunotherapy. Urology 1995, 46(5):681-686, discussion 686-687.

35. Bukur J, Malenica B, Huber C, Seliger B: Altered expression of nonclassical HLA class Ib antigens in human renal cell carcinoma and its association with impaired immune response. Hum Immunol 2003, 64(11):1081-1092.

\section{Pre-publication history}

The pre-publication history for this paper can be accessed here: http://www.biomedcentral.com/1471-2490/11/1/prepub

doi:10.1186/1471-2490-11-1

Cite this article as: Stickel et al:: Quantification of HLA class I molecules on renal cell carcinoma using Edman degradation. BMC Urology 2011

$11: 1$

\section{Submit your next manuscript to BioMed Central and take full advantage of:}

- Convenient online submission

- Thorough peer review

- No space constraints or color figure charges

- Immediate publication on acceptance

- Inclusion in PubMed, CAS, Scopus and Google Scholar

- Research which is freely available for redistribution

Submit your manuscript a www.biomedcentral.com/submit
C) Biomed Central 